\title{
Effects of Family Control on Degree and Type of Diversification: Empirical Evidence for Business Groups
}

\section{EXECUTIVE SUMMARY}

This paper analyses the impact of ownership structure on corporate diversification, with reference to large listed family business groups. By considering agency theory and socioemotional wealth, the study examines the relationship between family ownership, concentration of ownership, and degree and type of diversification. The study considers ninety-nine Spanish listed business groups (50 family-controlled- and 49 non-familycontrolled groups) and considers diversification of business group as the focus of analysis. The results show how family business groups present a lower preference for unrelated diversification than related diversification. There is also a non-linear relationship between concentration of ownership in family groups and degree of diversification, showing different behaviour in family groups according to shares owned by the family's leading shareholders. This paper contributes to literature by providing a more precise identification of the corporate strategy adopted by business groups and establishing new evidence about the impact of family control on diversification strategies and the differences regarding non-family business groups. KEYWORDS: Family Firm, Business Group, Diversification, Ownership Concentration, Socioemotional Wealth.

\section{Introduction}

In the last few years there has been a growing interest in analysing the influence of ownership and the nature of the major shareholders on diversification strategy (Lane et al., 1999; Goranova et al., 2007; Del Brio et al., 2010). Given the importance of family firms in the world economy (Moores, 2009) and the characteristics that distinguish them from non-family 
firms (Chrisman et al., 2005), family control could be a decisive factor for diversification, although new evidence is still required (Tsai et al., 2009; Daspit et al., 2017).

While non-family firms pursue profit maximization, family firms also seek the achievement of non-financial objectives such as survival and continuity, and the preservation of socioemotional capital (Arregle et al., 2007; Gomez-Mejia et al., 2010). This fact may cause a different strategic behaviour between family and non-family firms, and more specifically in terms of diversification (Anderson \& Reeb, 2003; Gomez-Mejia et al., 2010).

Anderson \& Reeb (2003) find that family firms use fewer product diversification strategies that non-family firms. Similar results obtained by Gomez-Mejia et al. (2010) indicate that, on average, family firms diversify less in both domestic and international markets than nonfamily firms. The conclusions obtained by these authors are corroborated by subsequent studies (Miller et al., 2010; Muñoz \& Sanchez, 2011; Muñoz et al., 2018). However, these studies analyze diversification from the point of view of a single unit, the firm. This leads to a distorted vision of these companies' corporate strategies, given that many of them are parent companies of business groups, and the decision to diversify is taken at the level of business group rather than that of the parent company (Young et al., 2008),

A business group is defined as an organization in which legally independent enterprises are controlled by the same entrepreneur (the parent company) through an ownership chain. On the other hand, a parent company is defined as a firm that owns enough voting stock in another company to control management and influence the election of the board of directors. Thus, a company is considered a dependent of a parent company either if the latter possesses more than fifty percent of the stock of the dependent company, or if it possesses a lower percentage of stock but still has the ability to exert effective control over the dependent company. In summary then, when analysing diversification, considering the parent company only takes into account one company, whereas if diversification is considered for the business group as a 
whole, that is, both for the parent company and the subsidiary companies, this enables a better analysis of the diversification strategies.

In many studies about business groups, diversification is considered an exogenous variable that influences performance (Wan \& Hoskisson, 2003; Fauver et al., 2003). Very few studies have considered diversification as an endogenous variable and analysed the influence of family ownership as a determining factor of diversification of a business group. Fauver et al. (2003) conclude that a greater concentration of ownership decreases the degree of diversification of business group, results confirmed by other authors (Delios et al., 2008; Chen and Yu, 2011). In addition, Chung (2013) finds that 'family management and family ownership play key roles in diversification decisions in family business groups... where likelihood of diversification declines as a controlling family assigns more family members to an affiliate firm's key leadership positions' .

However, previous works have focused on the analysis of the degree of diversification, without taking into account the type of diversification (related and unrelated diversification). In this regard, the following question arises: does the family firm show greater preference for related diversification or for unrelated diversification? These strategic options are only rarely considered, and with inconclusive results. Ducassy \& Prevot, 2010 find that there is no difference between family and non-family businesses in terms of the choice of diversification type (related or unrelated). On the other hand, Miller et al. (2010) find a positive relationship between family control and related diversification and a negative relationship between family control and unrelated diversification. Therefore, in the literature there is a need to study in greater depth the type of diversification strategy preferred by those companies controlled by family members.

In the same way, the non-linear relationship between family ownership and diversification is rarely analysed. Although Anderson \& Reeb (2003) and Chen \& Yu (2011) analyse it 
when talking about total diversification, there is no research where this quadratic model is proposed for related and unrelated diversification. In this regard, this paper seeks to provide new contributions to overcoming this gap, exploring whether a greater concentration of ownership in the hands of the family may condition a greater or lesser preference for related or unrelated diversification.

In line with this research, the objective of this study is to analyse the impact of family control on type of diversification (related and unrelated) in large Spanish listed family business groups, and thereby to try to determine whether one type of diversification strategy is preferred over the other. In addition, the existence of a non-linear model between family ownership and the degree of related and unrelated diversification is proposed.

This paper contributes to the literature on family firms and diversification in several ways. First, the paper uses business group as the unit of analysis of diversification. It allows a better identification of diversification strategy, avoiding the omissions that occur when the activities only of the parent company are analysed rather than of the business group as a whole.

Second, the paper aims to contribute to filling the gap that exists in studies of the preference of family business groups for related and unrelated diversification strategies. Additionally, the existence of a non-linear model is proposed for related and non-related diversification, an aspect not analysed in the literature.

The paper is structured as follows: firstly, the theoretical framework is presented that establishes the impact of family control on degree and type of diversification, starting with agency theory and supported by the concept of socioemotional wealth. Secondly, the database, variables and econometric techniques used to test hypotheses are described. Thirdly, the main results of the econometric models are analysed. Finally, the main conclusions, implications, limitations and future lines of research are presented. 


\section{Theoretical background and hypotheses}

According to agency theory, when concentration of ownership is very low, managers seek to satisfy their utility function, which includes aspects such as higher remuneration, higher prestige and lower personal risk of being fired (Amihud \& Lev, 1981; Jensen, 1986; Shleifer \& Vishny, 1986). A principal-agent problem arises due to the different interests between shareholders and managers (Jensen, 1986), thus increasing agency costs. Most of the literature that analyses the relationship between ownership and diversification is dominated by the model of the Anglo-Saxon firm, the latter characterized by dispersed share ownership and wide managerial discretion. Regarding diversification strategy, firms controlled by managers prefer diversification (Laeven \& Levine, 2007), since new products and activities enable managers satisfy their personal needs about their remuneration, power and personal risk (Sayrak \& Martin, 2001).

The manager-controlled firm is not the dominant form of business in Europe and Spain (La Porta et al., 1999). In Spain, ownership is highly concentrated, which results in the principalagent agency problem being reduced (Amihud and Lev, 1981). Thus, in Spain, differences in ownership come from differences between the groups of shareholders that have enough shares to control the firm, that is, families, financial entities, foreign capital, etc. In family firms, families seek to maximize the firm's value while keeping control in family hands (Shleifer \& Vishny, 1986). In these cases, family firms show less diversification than firms where managers have greater discretionary power (principal-agent problem), as there are no constraints regarding continuity of control (Anderson \& Reeb, 2003; Gomez-Mejia et al., 2010; Miller et al., 2010). Family control prevents diversification processes that may compromise the survival of the company, as it may occur in cases where diversification is the result of the principal-agent problem rather than the aim of creating value (Berger \& Ofek, 1995). 
However, when most of the family's wealth is invested in the firm, this increases its financial risk (Shleifer \& Vishny, 1997), and diversification could be an attractive strategy, reducing the firm's risk, variability of income and expected results (Eisenmann, 2002) in order to prevent bankruptcy (Storey, 1994). Nonetheless, family firms not only maximize their utility according to financial results and reduction of supported risk, but they also value other socioemotional aspects that can influence degree of diversification (Gomez-Mejia et al., 2010). According to Cennamo, Berrone, Cruz \& Gomez-Mejia (2012), the concept of socioemotional wealth includes: the desire to maintain family control of the firm; the desire to ensure the firm's survival in order to be subsequently passed on to later generations; the family's identification with the firm; the establishment of long-lasting relationships with different stakeholders; and emotional links that favour trust, loyalty, motivation and commitment. However, the intensity of preferences for the aforementioned desires can differ between family firms, giving rise to different behaviour with respect to diversification, as will be seen later.

In the firm- or business-group growth process, families can decide on different diversification strategies (diversification in related businesses or in unrelated businesses). Although both types present costs for the business group (Denis et al., 2002), they also involve a series of advantages. Diversification in related businesses makes better use of economies of scale and scope (Barney, 1991; Montgomery, 1985), accruing benefits from the firm's core activity and consumer base (Newbound et al., 1978). Related diversification also makes better uses of the business's main resources and capabilities, is less complex and less costly for the group (Markides \& Williamson, 1994). For a business group owned by family members, this strategy can allow greater value creation to be achieved (Park \& Soo Cheong, 2013), which can compensate any loss of socioemotional wealth derived from diversification process. On the other hand, unrelated diversification reduces income variability and financial 
risk to a lesser extent by focusing on businesses and activities with non-correlated cash flows (Shleifer \& Visnhy, 1986; Amit \& Livnat, 1988). However, this type of diversification does not allow synergies between activities.

When it comes to prefer one type of diversification or the other, since the pioneer study by Rumelt (1974), the literature shows superior performance and productivity in related diversification (Gomes \& Livdan, 2004; Park \& SooCheong, 2013), and a negative impact of unrelated diversification on profits and productivity (Berger \& Ofek, 1995; Tanriverdi \& Venkatraman, 2005; Chang \& Wang, 2007). The literature also reveals that unrelated diversification tends to be more used in firms where share ownership is more dispersed and where managers can exercise greater discretion, seeking to satisfy their personal interests at the cost of value creation and business results (Denis et al., 1997).

Unrelated diversification involves higher costs, more uncertainty and a greater need for financial resources, requiring the use of external sources of financing, and family business groups are more reluctant to implant such diversification as they seek to maintain the family's control of the business group (Miller \& Le Breton Miller, 2009). Unrelated diversification can require new resources and skills, with no synergies created from the resources already available in the family. The family could lack the know-how and skills required in the new businesses (McConaughy, 2000; Schulze et al., 2003), whereas those acquired in their current operations could be used more effectively in more similar activities. A family business group will opt for lower levels of unrelated diversification to preserve its socioemotional wealth (i.e., to retain control of the enterprise, to preserve familial relations, etc.), although this involves increasing financial risk or turning down new investments that would improve the business's economic position (Gomez-Mejia et al., 2010).

Related diversification can take advantage of synergies between the original activities and new activities. Family members will invest in activities that generate fewer costs and less 
uncertainty, preferring those related diversification strategies that are better at preserving socioemotional wealth (Gomez-Mejia et al., 2007) and do not harm the social capital based on familial relations. For all these reasons, when business group is owned by family members, it is expected to be willing to diversify more in related activities than diversify in unrelated activities. This leads to the first hypothesis:

Hypothesis 1: If a business group diversifies, greater family control means a lower preference for unrelated diversification than related diversification.

In family business groups, family control reduces the principal-agent problem (Fama \& Jensen, 1983; Miller \& Le Breton Miller, 2006), as the family's interests align with those of the other shareholders and aim at creation of value and survival of the business group (Arregle et al., 2007). A family firm will adopt strategies that optimize their results, subject to the constraint of maintaining family control of resources (Jones et al., 2008). Since diversification can lead to a loss of family control and a loss of socioemotional wealth, family members prefer lower diversification levels (Gomez-Mejia et al., 2010).

However, where the family has ensured control of the business group, if the level of family ownership concentration is very high a principal-principal problem can arise (Zahra, 2005; Aguilera \& Crespi-Cladera, 2012). The family can increase the level of diversification strategy in order to reduce risk even when it could be harmful for the other, non-family minority shareholders (Johnson et al., 2000). Therefore, family control has a double effect on diversification, depending on higher or lower levels of concentration of ownership; hence a non-linear model could be considered to relate concentration of family ownership and degree of diversification.

When the wealth of family members is committed to the firm, they support a greater financial risk, and there are incentives to reduce it to a minimum (Demsetz \& Lehn, 1985; Faccio et al., 2001). Participation in new businesses enables the family to reduce the firm's 
risk and the variability of its results (Eisenmann, 2002), although this also risks the possible loss of socioemotional wealth derived from diversification. In the literature, it is found that high levels of family ownership lead to increased diversification (Chen \& Yu, 2011; George \& Kabir, 2012), and the presence of an inverted u-shape relationship between family ownership and divestment likelihood is shown (Praet, 2013). So the following question arises: do high levels of family ownership concentration cause a change in the attitude of the family towards the diversification strategy?

Agency theory establishes a double impact of family ownership in diversification. First, as the family increases its stake in the share capital of the company the total degree of diversification is reduced, because the principal-agent agency problem diminishes; beyond a certain level, however, a principal-principal problem can arise between the family and the other non-family minority shareholders (Pindado et al., 2014). The high financial risk taken by family members facilitates the application of diversification strategies.

According to the socioemotional-wealth perspective, the concentration of family ownership can have a double effect on degree of diversification. At first, when concentration of family ownership increases, family interest in diversification of the business group decreases in order to preserve socioemotional wealth (Berrone et al., 2012). However, the concept of socioemotional wealth also includes the survival of the company and its transfer to later generations. When the family wealth invested in the business group is high, the family's risk significantly increases, which can endanger the survival of the firm. However, the family members can diversify as a means of reducing risk and improving survival.

There are circumstances in which family firms can benefit from the advantages of diversification even when diversification negatively impacts on socioemotional wealth (Gomez-Mejia et al., 2010). Although family control negatively impacts the level of diversification, the relationship between both can be affected by ownership concentration. 
When shares held by family members that control the business group are not very high (lower levels of family ownership), preservation of socioemotional wealth has a greater importance than the risk reduction. Family members renounce the positive effects of diversification on risk reduction in favour of family control of the company. On the other hand, when the control of business group is exerted by family members, an additional increase in the shares held by family members (higher levels of family ownership) causes a greater desire to decrease family risk, seeking to ensure the survival of the business group. In sum, concentration of ownership in family groups influences the application of diversification strategies, although the effect can be two-fold (Chen \& Yu, 2011; Praet, 2013). This leads to the second hypothesis:

Hypothesis 2: The relationship between concentration of family ownership and degree of total diversification is non-linear; it is negative at low levels of concentration of ownership and positive at high levels.

The above arguments are also valid concerning the relationship between family ownership concentration and type of diversification (the existence of U-shaped relationship between family ownership concentration and the degree of related and unrelated diversification). At first, increases of shares held by family members have a negative influence on related and/or unrelated diversification (family control of business group is prioritized with respect the decrease of risk). However, above a certain level, a higher concentration of family ownership promotes unrelated diversification (where a business group is owned by a family, risk reduction is more important to ensure survival and therefore preserve socioemotional wealth).

Related diversification aims to make use of all production factors to obtain synergies between activities, while unrelated diversification primarily aims to reduce the firm or business group's global risk. When family firms invest in new activities with a low cash-flow correlation (unrelated diversification), their financial risk is reduced to a greater extent than 
when related diversification strategies are used (Shleifer \& Visnhy, 1986; Amit \& Livnat, 1988).

Therefore, as greater concentration of ownership can cause a principal-principal agency problem, whereby the family seeks to reduce the firm's risk, concentration of ownership would have a greater impact on the degree of unrelated diversification, with degree of diversification possibly following a non-linear model. On the other hand, having ensured control of the firm, the family could seek to satisfy its own interests, appropriating part of the wealth of minority shareholders, and this is easier by means of unrelated diversification (Chen \& $\mathrm{Yu}, 2011)$. When diversifying in unrelated businesses, it is easier to use 'tunnelling' practices to transfer wealth from minority to majority shareholders, in this case family members (Kali \& Sarkar, 2011). This leads to the following hypothesis:

Hypothesis 3: The relationship between concentration of family ownership and degree of related and unrelated diversification is non-linear (it is negative at low levels of concentration of ownership and positive at high levels).

\section{Research methodology}

\subsection{Sample and data sources}

The initial sample consists of 112 companies listed on the Spanish stock markets in 20002005. After eliminating firms with missing data and outliers, the final sample consists of 99 firms that lead business groups (i.e., all listed companies have subsidiaries), and final panel data consists of 594 observations.

As mentioned in previous sections, a business group is defined as an organization in which legally independent enterprises are controlled by the same entrepreneur (the parent company) through an ownership chain. Thus, a company is considered a dependent of the parent company either if the latter possesses more than fifty percent of the stock of the dependent 
company, or if it possesses a lower percentage of stock but still has the ability to exert effective control over the dependent company. Firms that form part of pyramidal groups dependent on listed parents companies were identified by means of accounts summaries. This information is provided by the Spanish National Stock Market Commission (CNMV).

Values of the diversification variable were calculated from the information available in the SABI-Informa database, which contains precise information about non-listed firms controlled by listed parent companies, identifying their main activities and turnover. To identify the main activities, SABI-Informa uses the CNAE 93 Rev.1, a Spanish Economic Activity Classification that uses a four-digit code to identify and classify companies according to their economic activity. It is an adaptation of the European NACE and similar to the Standard Industrial Classification, SIC. This variable, together with the turnover (also provided by Sabi-Informa), allows diversification to be measured using the entropy index (Jacquemin \& Berry, 1979; Palepu, 1985), as will be seen in the following section.

The CNMV website was also used to identify family-run parent companies, analysing significant shareholdings, treasury stock and corporate governance reports. If in doubt, recourse was made to the SABI-Informa database and secondary sources of information such as the press and the sample firm's websites. Both sources (CNMV and SABI-Informa) were also used to obtain the accounting and financial information required.

\subsection{Variables of the study}

\section{Dependent variables: diversification.}

When measuring degree and type of diversification, most research only considers parent company activities (Kang, 1999; Anderson \& Reeb, 2003; Villalonga \& Amit, 2006; GomezMejia et al., 2010). However, it would appear to be more pertinent to consider the activities of the entire business group, including both the parent company and the pyramidal group of dependent firms. Diversification is thus measured more objectively, as the activities of 
dependent firms also form part of the parent company's overall strategy. Furthermore, analysis of the business group more easily identifies related and unrelated activities.

Diversification in the analysed business groups was defined by quantitative variables. To measure business-group diversification, a wide variety of diversification indices may be created (Rumelt, 1982), such as Gort's, index, Herfindhal index, Gini index, etc. In this paper entropy indices were used to measure total, related and unrelated, diversification (Jacquemin $\&$ Berry, 1979; Palepu, 1985), because these indices are considered in the literature to be the most suitable (Hoskisson et al., 1993). Compared to other indices, the entropy index takes into consideration the number of segments in which a firm operates and the relative importance of each of the segments in the total sales of the firm. Moreover, the entropy index is useful in the sense that it can be decomposed into components showing inter-industry (not-related) and intra-industry (related) diversification (Jacquemin \& Berry, 1979).

To calculate diversification indices, we had to identify the core activities of both the parent company and its dependent firms (available in SABI-Informa), incorporating the respective turnover values (Jacquemin \& Berry, 1979; Palepu, 1985):

To calculate diversification indices, we had to identify the core activities of both the parent company and its dependent firms (available in SABI-Informa), incorporating the respective turnover values (Jacquemin \& Berry, 1979; Palepu, 1985):

a) Entropy index of Total Diversification (TOTAL DIVERSIFICATION):

$$
T D=\sum_{i=1}^{n} S_{i} \ln \frac{1}{S_{i}}
$$

Where $S_{i}$ is the proportion of activity (turnover) in CNAE93 Rev.1 code "i", for a group with " $n$ " number of activities. This measure reflects the number of activities performed by the group and the importance of each activity. Different activities are activities with different CNAE93 Rev. 1 codes (4 digits). 
b) Entropy Index of Related Diversification (RELATED DIVERSIFICATION):

$$
R D=\sum_{j=1}^{m} R D_{j} S^{j}, \text { where } R D_{j}=\sum_{i \in j}^{n} S_{i}^{j} \ln \frac{1}{S_{i}^{j}}
$$

Where $S^{j}$ is the share of industrial sector " $\mathrm{j}$ " in the firm's total turnover, $\mathrm{RD}_{\mathrm{j}}$ is degree of related diversification, $S_{i}{ }^{j}$ is the share of activity "I", belonging to industrial sector " $\mathrm{j}$ ", in the group's total turnover, " $\mathrm{n}$ " is the number of activities and "m" the number of industrial sectors. Activities are considered with regards to 4 digits, while sectors are established according to the first two CNAE93 Rev. 1 digits.

c) Entropy index of Unrelated Diversification (UNRELATED DIVERSIFICATION):

$$
U D=\sum_{j=1}^{m} S^{j} \ln \frac{1}{S^{j}}
$$

Where $\mathrm{S}^{\mathrm{j}}$ is the share in total group turnover in industrial sector " $\mathrm{j}$ ", and $\mathrm{m}$ is the number of sectors. Activities are considered with regards to 4 digits, while sectors are established according to the first two CNAE93 Rev. 1 digits.

Independent variables: family firm and concentration of ownership.

A group is considered to be under a family's control when the family (family members) owns the most important shareholding (directly and indirectly) in the listed parent company, and one or several family members occupy key management positions and sit on the Board of Directors (Chua et al., 1999; Miller \& Le Breton-Miller, 2006). Family members were identified based on same surnames plus an analysis of the presence of married couples. In Spain it is important to note that family ties can be found due the two-surname system: women never take their husband's surname, whereas children take both their father's and mother's surnames (first and second surname). A group is thus a family enterprise (FAMILY) when the parent company remains under family control throughout the study period, with no changes in the last owner during that time. The correct classification of family business groups was verified by analysing horizontal and vertical ownership chains using the method 
proposed by La Porta et al. (1999) and used in subsequent studies (Claessens et al., 2000; Faccio et al., 2001). In both cases, classification of family groups is consistent with that applied in this study, with no discrepancy in the familial nature of the group. This is because Spain is characterized by high levels of family ownership concentration. The dummy variable FAMILY is used where 1 represent a group controlled by family members and 0 otherwise.

Degree of concentration of ownership is measured by the shares in the hands of the listed parent company's five leading shareholders (\% 5 MAIN SHAREHOLDERS) (Kang, 1999). This variable reflects the degree of managerial discretionality, as greater concentration of ownership reduces the discrepancy between the interests of managers and shareholders, limiting such discretionality (Shleifer \& Vishny, 1997).

\section{Control variables}

In the paper, several control variables are considered (Kang, 1999; Anderson \& Reeb, 2003; Ducassy \& Prevot, 2010; Gomez-Mejia et al., 2010; Miller et al., 2010; Chen \& Yu, 2011): a) size (LN SIZE), measured as the logarithm of total parent company assets; b) age (LN AGE), measured as the logarithm of the difference between 2000 and the year of establishment of the listed parent company; c) indebtedness (DEBT), measured as the ratio between the total debt and total assets of the listed parent company; d) capital intensity (CAPITAL INTENSITY), measured as the ratio between total material and immaterial fixed assets and number of employees of listed parent company; e) intangible assets (INTANGIBLE), representing the listed parent company's investment in new technologies and measured as the ratio between intangible and total assets; f) degree of managerial discretion, measured as the difference between the firm's economic returns and mean economic returns for the year of the sample (ECONOMIC RETURN - ECONOMIC RETURN YEAR), which enables us to analyse degree of managerial discretion in decision-making; b) structural change (STRUCTURAL CHANGE DUMMY), a dummy variable that is 1 when there has been a structural change in 
the listed parent company and 0 otherwise. In the regressions, it is also controlled for year dummy variables.

\subsection{Econometrics}

The present study examines differences in the mean of the model's variables according to the nature of main shareholder of control of business group, and correlations between the different study variables. To estimate the impact of family control and concentration of family ownership on the group's degree and type of diversification, panel data are used (the database comprises a sample of 99 listed parent companies over a 6-year period). Unobservable heterogeneity is controlled for to avoid biased results being obtained (Wooldridge, 2002). After verifying the existence of unobservable heterogeneity (by the Bresuch-Pagan Lagrange multipliers test), is necessary to determine the existence of heteroskedasticity and autocorrelation problems. To solve heteroskedasticity and autocorrelation problems when working with panel data, Panel Corrected Standard Errors (PCSE) or Feasible Generalized Least Squares (FGLS) estimators can be used (Cameron \& Triverdi, 2010). PCSE technique has been chosen because standard errors are more precise and it is among the most used in estimating panel data (Beck, 2001; Beck and Katz, 1995). PCSE preserves the weighting of observations for autocorrelation, but uses a sandwich estimator to incorporate cross-sectional dependence when calculating standard errors, while FGLS produces inaccurate coefficient standard errors (Mantobaye, Rea \& Reed, 2017).

Next, it is necessary to determine the use of fixed effects (unobservable heterogeneity correlated with the explanatory variables) or random effects (unobservable heterogeneity not correlated with the explanatory variables) in the model. Considering the possible presence of heteroskedasticity and autocorrelation, which affect the validity of estimations, the Wald test proposed by Wooldridge (2002) is used to select the most appropriate model (fixed or random effects) because the Hausman test is not valid when there are problems of either 
heteroskedasticity or autocorrelation, or both (Woolridge, 2002). The Wald-Wooldridge test compares estimations of the fixed-effects model and random-effects model. If systematic differences are found (the null hypothesis of equality is rejected) there still a correlation between the error and the regressors, and it is preferable to choose the fixed-effects model. Otherwise the random-effects model is chosen (Woolridge, 2002).

Presence of multicollinearity and heteroskedasticity are tested in econometric models. To establish the presence of multicollinearity, VIF values of the respective multiple linear regression and tolerance are estimated. If they are less than 0.1 or more than 10 , respectively, this shows the existence of multicollinearity. The absence of multicollinearity was checked in all the regressions in this study. The Wald-Wooldridge test for groupwise heteroskedasticity in fixed and random effects was performed to check for heteroskedasticity in panel data models (fixed and random). The results are robust to concerns of heteroskedasticity. All the models were estimated using the STATA 10.1 econometric program.

\section{Results and Discussion}

\subsection{Descriptive Statistics}

The sample consists of 50 business groups in which the listed parent company is controlled by family shareholders and 49 business groups controlled by non-family shareholders. This confirms the importance of families on the stock market, and is consistent with the findings of previous studies (Sacristán et al., 2011).

Table 1 analyses the difference in means of the main study variables according to family control of business group, showing correlations between the model's different variables. When analysing diversification, family business groups present a lower degree of total and unrelated diversification, with no differences in degree of related diversification. 
Listed parent companies controlled by family members show greater concentration of ownership, are less intensive in productive capital, are smaller and have been involved in a smaller number of mergers and takeovers. In relation to mean dispersion in 'return on firm investment relative to mean return on investment of sample firms', there are differences between family and non-family parent companies, with less managerial discretionality in the former. When analysing correlations between the model variables, family groups present a negative correlation with diversification (total, related and unrelated), confirming the previously mentioned results. They also show a positive relationship with concentration of ownership and a negative relationship with size of listed company, age, investment in intangible assets and involvement in mergers and takeovers. Also, greater concentration of ownership in the hands of five leading shareholders is negatively related to the different types of diversification and to the size of the parent company, and positively to the difference between mean returns of the parent company and mean returns of sample firms in the year in question. On the other hand, the diversification variables, regardless of type, are positively related to size of parent company and to the variable representing structural changes resulting from mergers and takeovers, and are negatively related to differences in returns. Except for related diversification, in the other variables that measure degree of diversification (total and unrelated), there is a positive relationship with indebtedness and a negative relationship with capital intensity.

\subsection{Family Control and Diversification}

Table 2 presents the results of panel data models, showing the impact of family control of the business group on degree of total, related and unrelated diversification. The use of panel data is justified by the presence of unobservable heterogeneity in all the models. After verifying the presence of heteroskedasticity and autocorrelation, the Wald test proposed by Wooldridge (2002) shows the existence of random effects in the models used to analyse total and 
unrelated diversification, while there are fixed effects in the related diversification model. The significance of Hausman's chi-square supports the validity of the presented models..

\section{INSERT TABLE 2 HERE}

The first significant observation is the zero impact of family control on degree of total diversification (see model 1 in Table 2), so that family and non-family groups present the same behaviour. Regarding degree of related and unrelated diversification, Table 2 shows how family groups diversify less in unrelated activities than non-family groups (see model 3 in Table 2), and there are no differences between family and non-family groups when it comes to diversifying in related activities (see model 2 in Table 2), supporting hypothesis H1.

Table 3 analyses the possible non-linear relationship between degree of diversification and concentration of ownership in family groups. The model thus contemplates the percentage of shares owned by the five leading shareholders when the group is under family control (\% 5 MAIN SHAREHOLDERS * FAMILY) and its value squared. As with the previous models there is unobservable heterogeneity; random-effects models are more appropriate for analysing the degree of total and unrelated diversification and fixed-effects models for related diversification. Table 3 shows a non-linear relationship between concentration of ownership in family groups and diversification (see model 1 in Table 3). Initially, increased concentration of ownership of family groups has a negative impact, although beyond a certain level of family control, further increases in family ownership favour diversification (hypothesis H2 is supported). Although family ownership of a business group had no impact on the degree of total diversification on Table 2, this could be because of the compensation effect derived from the dual impact (both negative and positive) of concentration of ownership on diversification in family groups.

With regards to type of diversification, Table 3 confirms the null impact of family control on related diversification (see model 2 in Table 3), while the existence of a non-linear 
relationship (see model 3 in Table 3 ) between concentration of family ownership and degree of unrelated diversification is also confirmed (U-shaped model between family ownership and diversification), supporting hypothesis H3 for unrelated diversification.

\section{INSERT TABLE 3 HERE}

\subsection{Discussion of Results}

In general terms, the impact of family ownership on degree of diversification is confirmed (Anderson \& Reeb, 2003; Miller \& Le Bretton Miller, 2006), and specifically, a non-linear relationship is established as a function of concentration of ownership in family groups, with a negative impact with moderate concentration of ownership and a positive impact when concentration of ownership is greater (Anderson \& Reeb, 2003; Chen \& Yu, 2011). Initially, the family acquires the shares required to maintain control of the business group. In this situation, the interests of shareholders and managers (who are often family members) are aligned, reducing the type I agency problem (Fama \& Jensen, 1983; Miller \& Le Breton Miller, 2006), and seek the business group's survival, so they will prefer lower degrees of diversification than non-family groups (Goranova et al., 2007). In this case, performing new activities reduces the independence of the family, causing a reduction in socioemotional wealth (Gómez-Mejia et al., 2010).

When analysing possible differences between family and non-family groups according to different types of diversification, the study finds that family groups prefer similar degrees of related diversification compared to non-family groups (Ducassy \& Prevot, 2010), although family ownership has a negative impact on the use of unrelated diversification strategies (Miller et al., 2010). Unrelated diversification can reduce the risk supported by the family (Larraza, et al., 2004), but the need for new resources and skills (Schulze et al., 2002), greater organisational complexity (Eisenmann, 2002), lack of skills and know-how among family members (Schulze et al., 2003), and possible loss of socio-emotion wealth (Gomez-Mejia et 
al., 2007) explain why this strategy is used less by family groups. The conclusion is that family groups prefer to diversify in related rather than unrelated businesses (Kang, 1999).

Note that there is a non-linear relationship between concentration of family ownership and degree of unrelated diversification; with moderate unrelated diversification, concentration of family ownership diminishes the degree of such diversification, although it starts to increase at a given point. When the family has high levels of ownership, in order to reduce the risk supported by the family (Larraza et al., 2004), family groups prefer greater degrees of unrelated diversification.

\section{Conclusions}

This paper analyses the impact of family control and concentration of ownership on diversification strategies (related and unrelated) in large Spanish business groups in which the parent company is listed. It is based on a sample of 99 groups with listed parent companies, identifying those that are under family control and the estimating degree of total, related and unrelated diversification.

The study shows the existence of a negative influence of family control on unrelated diversification (Miller et al., 2010), but no relationship between family control and related diversification, and this shows that there is a lower preference for unrelated diversification compared to related diversification. This represents a new contribution to literature, with few studies analysing the influence of family on the type of diversification (Gomez-Mejia et al., 2010; Larraza et al., 2004; Miller et al., 2010). Business groups owned by family members will invest in activities that generate fewer costs and less uncertainty, preferring related diversification strategies that preserve more socioemotional wealth (Gomez-Mejia et al., 2007). Family groups prefer diversification strategies that have a positive impact on performance (Gomes \& Livdan, 2004) and show a decreased interest in unrelated 
diversification because it is more complicated and difficult than related diversification (Eisenmann, 2002). Unrelated diversification involves higher costs, more uncertainty, greater need for financial resources (usually external), and new skills and know-how (Schulze et al., 2003; Miller \& Le Breton Miller, 2009), thus related diversification strategies that allow a better use of economies of scale and scope, and enable more synergies, are more attractive for family members (Wan et al., 2011). Additionally, related diversification allows better control of the business group for family members (Miller \& Le Breton Miller, 2009).

With regard to the concentration of ownership in family groups, the study shows a nonlinear relationship with degree of diversification, which decreases (total and unrelated) as concentration of ownership grows; however, from a certain level, increases in concentration of ownership in family groups increase the degree of diversification (total and unrelated). To being with, as the family increases its stake in the share capital of the company, the degree of diversification is reduced, because the principal-agent agency problem diminishes and family interest in diversification of business group decreases in order to preserve socioemotional wealth (Berrone et al., 2012). However, when the family wealth invested in the business group becomes high, participation in new businesses enables the family to reduce the firm's risk and the variability of its results (Eisenmann, 2002), and to seek to ensure the survival of the business group, an important element of social-emotional wealth. When control of the business group is exerted by family members, an additional increase in the shares held by family members (higher levels of family ownership) causes a greater desire to decrease family risk and to seek to ensure the survival of the business group. The non-linear model does not occur in the case of related diversification, since an increase in the number of related activities does not allow for risk diversification, but rather the opposite. 


\section{Contributions, limitations and suggestions for future research}

This research makes several contributions. Firstly, diversification is measured by considering business groups, facilitating the identification of related and unrelated activities and showing more appropriately the group's strategy. Secondly, the study provides new evidence of the impact of ownership structure of business groups with listed parent companies on related and unrelated diversification, together with the existence for family business groups of a nonlinear relationship between degree of diversification and concentration of ownership. Both agency and the socioemotional wealth theories are used to support our hypothesis.

Finally, the study shows how family ownership is a key factor in strategic decisions, more specifically in diversification decisions. The duality between family control and risk reduction has a double effect on socioemotional wealth, conditioning growth decisions.

The research, however, does have a series of limitations. Firstly, it compares family and non-family groups, while it could be more appropriate to consider the ultimate owner of nonfamily business groups, whether they are controlled by banks, non-national companies, investment funds, the State, etc., as different objectives can have different effects on diversification strategies.

Secondly, the results are valid for business groups in which the parent company is listed, and cannot be generalized to family groups or firms that are smaller and/or unlisted. Another possible line of research is therefore to establish the relationship between family ownership, concentration of ownership and diversification for unlisted business groups.

Thirdly, it would be interesting for family groups to analyse the current generation in both business ownership and management in more detail, considering the presence of the founder, and his or her children or cousins. According to Gomez-Mejia and others (2007), the desire to preserve socioemotional wealth varies in different generations; as ownership is diluted in subsequent generations (children, cousins), socioemotional wealth is less important for the 
utility function of family members. Financial risk and risk minimisation becomes more important, involving a more positive attitude to diversification strategies.

Finally, it should be pointed out that Spain is characterized by a legal system, based on civil law, that has an institutional and regulatory framework to protect minority stockholders and that is weaker than the institutional framework of the United States or the United Kingdom (La Porta et al., 1999); this explains Spain's greater concentration of company holdings in general and its greater concentration of holdings in family businesses in particular. It would be interesting to carry out the study for other countries because this would allow the verification of possible differences in group diversification according to the existing institutional framework in the country (Wan \& Hoskisson, 2003).

\section{References}

Aguilera, R.V., \& Crespi-Cladera, R. (2012). Firm family firms: Current debates of corporate governance in family firms. Journal of Family Business Strategy, 3(2), 66-69. https://doi.org/10.1016/j.jfbs.2012.03.006

Amihud, Y., \& Lev, B. (1981). Risk reduction as a managerial motive for conglomerate mergers. Bell Journal of Economics, 12(2), 605-617. Doi: 10.2307/3003575

Amit, R., \& Livnat, J. (1988). Diversification strategies, business cycles and economic performance. Strategic Management Journal, 9(2), 99-110. https://doi.org/10.1002/smj.4250090202

Anderson, R.C., \& Reeb, D.M. (2003). Founding-Family ownership, corporate diversification and firm leverage. Journal of Law and Economics, 46(2), 653-684. https://doi.org/10.1086/377115

Arregle, J.L., Hitt, M.A., Sirmon, D.G., \& Very, P.V. (2007). The development of organizational social capital: Attributes of family firms. Journal of Management Studies, 44(1), 73-95. https://doi.org/10.1111/j.1467-6486.2007.00665.x

Barney, J.B. (1991). Firm resources and sustained competitive advantage. Journal of Management, 17(1), 99-120. https://doi.org/10.1177/014920639101700108

Beck, N. (2001). Time-series cross-section data: what have we learned in the past few years. Annual Review of Political Science, 4, 271-293. https://doi.org/10.1146/annurev.polisci.4.1.271

Beck, N. \& Katz, J. N. (1995) What to do (and not to do) with time-series crosssection data. American Political Science Review, 89(3), 634-647. http://dx.doi.org/10.2307/2082979 
Berger, P., \& Ofek, E. (1995). Diversification's effect on firm value. Journal of Financial Economics, 37(1), 39-65. https://doi.org/10.1016/0304-405X(94)00798-6

Berrone, P., Cruz, C., \& Gomez-Mejia, L.R. (2012). Socioemotional wealth in family firms: Theoretical dimensions, assessment approaches, and agenda of future research. Family Business Review, 25(3), 258-279. https://doi.org/10.1177/0894486511435355

Cameron, A.C. \& Trivedi, P.K. (2010): Microeconometrics using Stata. Texas, Stata Press Publication

Cennamo, C., Berrone, P., Cruz, C., \& Gomez-Mejia, L.R. (2012). Socioemotional wealth and proactive stakeholder engagement: Why family controlled firms care more about their stakeholders. Entrepreneurship Theory and Practice, 36 (6), 1153-1173. https://doi.org/10.1111/j.1540-6520.2012.00543.x

Chang, S., \& Wang, C. (2007). The effect of product diversification strategies on the relationship between international diversification and firm performance. Journal of World Business, 42(1), 61-79. https://doi.org/10.1016/j.jwb.2006.11.002

Chen, C.J., \& Yu, M.J. (2011). Managerial ownership, diversification, and firm performance: Evidence from an emerging market. International Business Review, 21(3), 518-534. https://doi.org/10.1016/j.ibusrev.2011.06.002

Chrisman, J.J., Chua, J.H., \& Sharma, P. (2005). Trends and directions in the development of a strategic management theory of the family firm. Entrepreneurship, Theory and Practice, 29(5), 555-576. https://doi.org/10.1111/j.1540-6520.2005.00098.x

Chua, J.H., Chrisman, J.J., and Sharma, P. (1999). Defining the family business by behaviour. Entrepreneurship, Theory and Practice, 23(4), 19-39. https://doi.org/10.1177/104225879902300402

Chung, H. M. (2013). The role of family management and family ownership in diversification: The case of family business groups. Asia Pacific Journal of Management, 30(3), 871-891. https://doi.org/10.1007/s10490-012-9284-x

Claessens, S., Djankov, S., \& Lang, L. (2000). The Separation of Ownership and Control in East Asian Corporations. Journal of Financial Economics, 58(1-2), 81-112. https://doi.org/10.1016/S0304-405X(00)00067-2

Daspit, J.J., Chrisman, J.J, Sharma, P., Pearson, A.W. \& Long, R.G. (2017). A strategic management perspective of the family firm: Past trends, new insights, and future directions. Journal of Managerial Issues, 29(1), 6-29

Del Brio, E., De Miguel, A., \& Tobar, J.E. (2010). Efectos de la regulación bursátil sobre la eficiencia de los mercados de valores. Comparación entre España y Reino Unido. Revista Española de Financiación y Contabilidad, 39(146), 321-342

Delios, A., Zhou, N. \& Xu, W.W. (2008). Ownership structure and the diversification and performance of publicly-listed companies in China. Business Horizons, 51(6), 473483. https://doi.org/10.1016/j.bushor.2008.06.004

Demsetz, H., \& Lehn, K. (1985). The structure of corporate ownership: causes and consequences. Journal of Political Economics, 93(6), 1155-1177. https://doi.org/10.1086/261354

Denis, D., Denis, D., \& Yost, K. (2002). Global diversification, industrial diversification, and firm value. Journal of Finance, 57(5), 1951-1979. https://doi.org/10.1111/00221082.00485 
Denis, D., Denis, D., \& Sarin, A. (1997). Agency problems, equity ownership, and corporate diversification. Journal of Finance, 52(1), 135-160. https://doi.org/10.1111/j.15406261.1997.tb03811.x

Ducassy, I., \& Prevot, F. (2010). The effects of family dynamics on diversified strategy: empirical evidence from French companies. Journal of Family Business Strategy, 1(4), 224-235. https://doi.org/10.1016/j.jfbs.2010.10.001

Eisenmann, T.R. (2002). The effects of CEO equity ownership and firm diversification on risk taking. Strategic Management Journal, 23(6), 513-534. https://doi.org/10.1002/smj.236

Faccio, M., Lang, L.H.P., \& Young, L. (2001). Dividends and expropriation. American Economic Review, 91(1), 54-78. https://doi.org/10.1257/aer.91.1.54

Fama, E., \& Jensen, M. (1983). Agency problems and residual claims. Journal of Law and Economics, 26(2), 301-325. https://doi.org/10.1086/467038

Fauver, L., Houston, J. \& Naranjo, A. (2003). Capital markets development, international integration, legal systems, and the value of corporate diversification: a cross-country analysis. Journal of Financial and Quantitative Analysis, 38(1). 135-157. https://doi.org/10.2307/4126767

George, R., \& Kabir, R. (2012). Heterogeneity in business group and the corporate diversification firm performance relationship. Journal of Business Research, 65(3), 412420. http://dx.doi.org/10.2139/ssrn.1857923

Gomes, J., \& Lidvan, D. (2004). Optimal Diversification: Reconciling Theory and Evidence. The Journal of Finance, 59(2), 507-535. https://doi.org/10.1111/j.15406261.2004.00641.x

Gomez-Mejia, L., Haynes, K., Nuñez, M., Jacobson, K., \& Moyano, J. (2007). Socioemotional wealth and business risks in family-controlled firms: Evidence from Spanish olive oil Mills. Administrative Science Quarterly, 52(1), 106-137. https://doi.org/10.2189/asqu.52.1.106

Gomez-Mejia, L., Makri, M., \& Larraza, M. (2010). Diversification decisions in familycontrolled firms. Journal of Management Studies, 47(2), 223-252. https://doi.org/10.1111/j.1467-6486.2009.00889.x

Goranova. M., Alessandri, T., Brandes, P., \& Dharwadkar, R. (2007). Managerial ownership and corporate diversification: A longitudinal view. Strategic Management Journal, 28(3), 211-225. https://doi.org/10.1002/smj.570

Hoskisson, R.E., Hitt, M.A., Johnson, R.A., \& Moesel, D.D. (1993). Construct validity of an objective (Entropy) categorical measure of diversification strategy. Strategic Management Journal, 14(3), 215-235. https://doi.org/10.1002/smj.4250140305

Jacquemin, A.P., \& Berry, C.H. (1979). Entropy measure of diversification and corporate growth. The Journal of Industrial Economics, 27(4), 359-369. http://dx.doi.org/10.2307/2097958

Jensen, M.C. (1986). Agency costs of free cash flow, corporate finance, and takeovers. American Economic Review, 76(2), 323-329. http://dx.doi.org/10.2139/ssrn.99580

Jones, C.D., Makri, M., \& Gomez-Mejia, L.R. (2008). Affiliate directors and perceived risk bearing in publicly traded, family-controlled firms: The case of diversification. 
Entrepreneurship: Theory and Practice, 32(6), 1007-1026. https://doi.org/10.1111/j.1540-6520.2008.00269.x

Johnson, S., La Porta, R., Lopez-de-Silanes, F., \& Shleifer, A. (2000). Tunneling. American Economic Review, 90(2), 22-27. https://doi.org/10.1257/aer.90.2.22

Kali, R., \& Sarkar, J. (2011). Diversification and tunnelling, evidence from Indian business groups. Journal of Comparative Economics, 39(3), 349-367. https://doi.org/10.1016/j.jce.2011.04.001

Kang, D.L. (1999). Ownership structure and the boundaries of the firm: how large-block family owners lead to increased vertical integration, diversification and superior firm performance. Academy of Management annual meeting: business policy and strategy division, January

La Porta, R., Lopez-de-Silanes, F., \& Shleifer, A. (1999). Corporate ownership around the world. Journal of Finance, 54 (2), 471-517. https://doi.org/10.1111/0022-1082.00115

Laeven, L., \& Levine, R. (2007). Is there a diversification discount in financial conglomerates?. Journal of Financial Economics, 85(2), 331-367. https://doi.org/10.3386/w11499

Lane, P., Cannella, A., \& Lubatkin, M. (1999). Ownership structure and corporate strategy: One question viewed from two different worlds. Strategic Management Journal, 20(11), 1077-1086. https://doi.org/10.1002/(SICI)1097-0266(199911)20:11<1077::AIDSMJ68>3.0.CO;2-O

Larraza, M., Makri, M., \& Gomez-Mejia, L. (2004). Propiedad familiar, participación accionarial del consejero delegado y diversificación. XIV Congreso nacional ACEDE, Murcia.

Mantobaye, W., Rea, W. \& Reed, W. (2018). Which panel data estimator should I use? A corrigendum and extention. Economics: The Open-Acces, Open-Assessment E-Juornal, 12(4), 1-31. http://dx.doi.org/10.5018/economics-ejournal.ja.2018-4

Markides C., \& Williamson, P. (1994). Related diversification, core competences and corporate performance. Strategic Management Journal, 15(2), 149-165. https://doi.org/10.1002/smj.4250151010

McConaughy, D. L. (2000). Family CEO versus non-family CEOs in the family controlled firm: an examination of the level and sensitivity of pay to performance. Family Business Review, 13(2), 121-131. https://doi.org/10.1111/j.1741-6248.2000.00121.x

Miller, D., \& Le Breton-Miller, I. (2009). Agency vs. stewardship in public family firms: social embeddedness reconciliation. Entrepreneurship: Theory and Practice, 33(6), 1169-1191. https://doi.org/10.1111/j.1540-6520.2009.00339.x

Miller, D., \& Le Breton-Miller, I., Lester, R.H. (2010). Family ownership and acquisition behaviour in publicly-traded companies. Strategic Management Journal, 31(2), 201214. https://doi.org/10.1002/smj.802

Miller, D., \& Le Breton-Miller, I. (2006). Family governance and firm performance: Agency, stewardship, and capabilities. Family Business Review, 19(1), 73-87. https://doi.org/10.1111/j.1741-6248.2006.00063.x

Montgomery, C. (1985). Product-market diversification and market power. Academy of Management Journal, 28(4), 789-798. https://doi.org/10.2307/256237 
Moores, K. (2009). Paradigms and theory building in the domain of business families. Family Business Review, 22(2), 167-180. https://doi.org/10.1177/0894486509333372

Muñoz, F. \& Sánchez, M.J. (2011). Do family ties shape the performance consequences of diversification? Evidence form the European Union. Journal of World Business, 47(3), 469-477. https://doi.org/10.1016/j.jwb.2011.05.013

Muñoz, F., Sánchez, M.J. \& Suárez, I. (2018). Diversification decisions among family firms: The role of family involvement and generational stage. Business Research Quarterly, 21(1), 39-52. https://doi.org/10.1016/j.brq.2017.11.001

Newbound, G., Buckley, P., \& Turwell, J. (1978). Going international: The experience of smaller companies overseas. Somerset, Halstead Press.

Palepu, K. (1985). Diversification strategy, profit performance and the entropy measure. Strategic Management Journal, 6 (3), 239-255. https://doi.org/10.1002/smj.4250060305

Park, K., \& SooCheong, J. (2013). Effects of within-industry diversification and related diversification strategies on performance. International Journal of Hospitality Management, 34, 51-60. https://doi.org/10.1016/j.ijhm.2013.02.009

Pindado, J., Requejo, I., \& De la Torre, C. (2014). Family control, expropriation, and investor protection: A panel data analysis of Western European corporations. Journal of Empirical Finance, 27, 58-74. https://doi.org/10.1016/j.jempfin.2013.10.006

Praet, A. (2013). Family firms and the divestment decision: An agency perspective. Journal of Family Business Strategy, 4, 34-41. http://dx.doi.org/10.1016/j.jfbs.2012.12.002

Rumelt, R.P. (1974). Strategy, structure and economic performance. Boston, Harvard University Press.

Rumelt, R.P. (1982). Diversification strategy and profitability. Strategic Management Journal, 3(4), 359- 369. https://doi.org/10.1002/smj.4250030407

Sacristán, M., Gomez, S., \& Cabeza, L. (2011). Large shareholders' combinations in family firm: Prevalence and performance effects. Journal of Family Business Strategy, 2(2), 101-112. https://doi.org/10.1016/j.jfbs.2011.03.001

Sayrak, A., \& Martin, J.D. (2001). Corporate Governance and the Performance of Diversified Firms, Unpublished manuscript, Baylor University.

Schulze, W.S., Lubatkin, M.H., \& Dino, R.N. (2002). Altruism, agency, and the competitiveness of family firms. Managerial and Decision Economics, 23(4-5), 247259. https://doi.org/10.1002/mde.1064

Schulze, W.S., Lubatkin M., \& Dino, R.N. (2003). Exploring the agency consequences of ownership dispersion among the directors of private family firms. Academy of Management Journal, 46(2), 179-194. http://dx.doi.org/10.2307/30040613

Shleifer, A., \& Vishny, R. (1986). Large shareholders and corporate control. Journal of Political Economy, 94(3), 461-488. Doi: 10.1086/261385

Shleifer, A., \& Vishny, R. (1997). A survey of corporate governance. Journal of Finance, 52(2), 737-783. https://doi.org/10.1111/j.1540-6261.1997.tb04820.x

Storey, D.J., (1994). New firm growth and bank financing. Small Business Economics, 6(2), 139-150. https://doi.org/10.1007/BF01065186 
Tanriverdi, H., \& Venkatraman, N. (2005). Knowledge relatedness and the performance of multibusiness firms. Strategic Management Journal, 26(1), 97-119. https://doi.org/10.1002/smj.435

Tsai, W., Kuo, Y., \& Hung, J. (2009). Corporate diversification and CEO turnover in family businesses: Self entrenchment or risk reduction?. Small Business Economics, 32(1), 5776. https://doi.org/10.1007/s11187-007-9073-y

Villalonga, B., \& Amit, R. (2006). How do family ownership, control and management affect firm value?. Journal of Financial Economics, 80(2), 385-417. https://doi.org/10.1016/j.jfineco.2004.12.005

Wan, W. P. \& Hoskisson, R. E. (2003). Home country environments, corporate diversification strategies, and firm performance. Academy of Management Journal, 46(1), 27-45. http://dx.doi.org/10.2307/30040674

Wan, W.P., Hoskisson R.E., Short, C., \& Yiu, D.W. (2011). Resource-based theory and corporate diversification: accomplishments and opportunities. Journal of Management, 37(5), 1335-1368. https://doi.org/10.1177/0149206310391804

Wooldridge, J.M. (2002). Econometric Analysis of Cross Section and Panel Data. Cambridge, MIT Press.

Young, M., Peng, M. W., Ahlstrom, D., Bruton, G. \& Jiang, Y. (2008). Governing the corporation in emerging economies: a review of the principal-principal perspective. Journal of Management Studies 45(1), 196-220. https://doi.org/10.1111/j.14676486.2007.00752.x

Zahra, S. A. (2005). Entrepreneurial risk taking in family firms. Family Business Review, 18(1), 23-40. https://doi.org/10.1111/j.1741-6248.2005.00028.x. 
Table 1: Differences in means of principal study variables according to family ownership of business group and correlations between study variables

\begin{tabular}{|c|c|c|c|c|c|c|c|c|c|c|c|c|c|c|c|}
\hline & $\begin{array}{r}\text { ME } \\
\text { FAMILY } \\
\end{array}$ & $\begin{array}{l}\text { ANN } \\
\text { NO } \\
\text { FAMILY }\end{array}$ & $\begin{array}{c}\text { T- } \\
\text { Student }\end{array}$ & $\begin{array}{c}\text { TOTAL } \\
\text { DIVERSIFICATION }\end{array}$ & $\begin{array}{l}\text { RELATED } \\
\text { DIVERSIFICATION }\end{array}$ & $\begin{array}{l}\text { UNRELALTED } \\
\text { DIVERSIFICATION }\end{array}$ & FAMILY & $\begin{array}{c}\% 5 \text { MAIN } \\
\text { SHAREHOLDERS }\end{array}$ & $\begin{array}{l}\text { LN } \\
\text { SIZE }\end{array}$ & $\begin{array}{l}\mathbf{L N} \\
\mathbf{A G E}\end{array}$ & DEBT & INTANGIBLES & $\begin{array}{c}\text { ECONOMIC } \\
\text { RETURN- } \\
\text { ECONOMIC } \\
\text { RETURN YEAR } \\
\end{array}$ & $\begin{array}{l}\text { CAPITAL } \\
\text { INTENSITY }\end{array}$ & $\begin{array}{l}\text { STRUCTURAL } \\
\text { CHANGE } \\
\text { DUMMY }\end{array}$ \\
\hline $\begin{array}{c}\text { TOTAL } \\
\text { DIVERSIFICATION }\end{array}$ & 0,50 & 0,73 & **** & 1 & & & & & & & & & & & \\
\hline $\begin{array}{c}\text { RELATED } \\
\text { DIVERSIFICATION }\end{array}$ & 0,15 & 0,18 & NS & $0,68^{\mathrm{a}}$ & 1 & & & & & & & & & & \\
\hline $\begin{array}{l}\text { UNRELALTED } \\
\text { DIVERSIFICATION }\end{array}$ & 0,34 & 0,54 & $* * *$ & $0,92^{a}$ & $0,34^{\mathrm{a}}$ & 1 & & & & & & & & & \\
\hline FAMILY & $50,50 \%$ & $49,50 \%$ & --- & $-0,26^{a}$ & $-0,19^{\mathrm{a}}$ & $-0,27^{\mathrm{a}}$ & 1 & & & & & & & & \\
\hline $\begin{array}{c}\% 5 \text { MAIN } \\
\text { SHAREHOLDERS }\end{array}$ & $65,96 \%$ & $\begin{array}{c}48,36 \\
\%\end{array}$ & **** & $-0,18^{a}$ & $-0,10^{b}$ & $-0,17^{\mathrm{a}}$ & $0,33^{\mathrm{a}}$ & 1 & & & & & & & \\
\hline $\begin{array}{l}\text { LN } \\
\text { AGE }\end{array}$ & 3,59 & 3,66 & NS & 0,01 & $-0,04$ & 0,03 & $-0,10^{\mathrm{b}}$ & 0,07 & $-0,01$ & 1 & & & & & \\
\hline DEBT & 0,37 & 0,39 & NS & $0,14^{\mathrm{a}}$ & 0,08 & $0,14^{\mathrm{a}}$ & $-0,05$ & 0,06 & $0,46^{a}$ & $0,11^{\mathrm{a}}$ & 1 & & & & \\
\hline INTANGIBLES & 0,02 & 0,03 & NS & 0,03 & $-0,02$ & 0,08 & $-0,12^{\mathrm{a}}$ & $-0,02$ & 0,02 & $-0,02$ & $0,10^{\mathrm{b}}$ & 1 & & & \\
\hline $\begin{array}{l}\text { ECONOMI RETURN- } \\
\text { EONOMIC RETRN YEAR }\end{array}$ & $-0,01$ & 0,01 & $* *$ & $-0,27^{\mathrm{a}}$ & $-0,12^{\mathrm{a}}$ & $-0,28^{\mathrm{a}}$ & $-0,03$ & $0,11^{\mathrm{a}}$ & 0,02 & $0,10^{\mathrm{b}}$ & $-0,11^{\mathrm{a}}$ & $0,12^{\mathrm{a}}$ & 1 & & \\
\hline $\begin{array}{l}\text { CAPITAL } \\
\text { INTENSITY }\end{array}$ & 4,56 & 4,84 & * & $-0,10^{b}$ & 0,07 & $-0,17^{\mathrm{a}}$ & $-0,02$ & $0,16^{\mathrm{a}}$ & $0,17^{\mathrm{a}}$ & 0,01 & $0,12^{\mathrm{a}}$ & $0,10^{\mathrm{b}}$ & 0,01 & 1 & \\
\hline $\begin{array}{c}\text { STRUCTURAL } \\
\text { CHANGE DUMMY } \\
\end{array}$ & $18 \%$ & $27 \%$ & $* *$ & $0,40^{\mathrm{a}}$ & $0,42^{\mathrm{a}}$ & $0,36^{\mathrm{a}}$ & $-0,10^{\mathrm{b}}$ & 0,03 & $0,58^{\mathrm{a}}$ & $-0,03$ & $0,20^{\mathrm{a}}$ & 0,04 & 0,010 & $0,10^{\mathrm{b}}$ & 1 \\
\hline
\end{tabular}

NOTE. Spearman's rank correlation for dummy variables; Pearson's correlation for non-dummy variables.

$* \mathrm{p}<.10 . * * \mathrm{p}<.05 . * * * .01 \mathrm{NS}$ : non-significant

a Correlation is significant at the 0.01 level (two-tailed)

b Correlation is significant at the 0.05 level (two-tailed) 
Table 2: Impact of family ownership on degree and type of diversification

\begin{tabular}{|c|c|c|c|}
\hline & $\begin{array}{c}\text { TOTAL } \\
\text { DIVERSIFICATION } \\
\text { PCSE (RE) } \\
\text { (Model 1) } \\
\end{array}$ & $\begin{array}{l}\text { RELATED } \\
\text { DIVERSIFICATION } \\
\text { PCSE (FE) } \\
\text { (Model 2) } \\
\end{array}$ & $\begin{array}{l}\text { UNRELATED } \\
\text { DIVERSIFICATION } \\
\text { PCSE (RE) } \\
\text { (Model 3) } \\
\end{array}$ \\
\hline FAMILY & $\begin{array}{l}-0.073 \\
(-1,26)\end{array}$ & $\begin{array}{c}-0,022 \\
(-0,34)\end{array}$ & $\begin{array}{c}-0,969^{* *} \\
(2,03)\end{array}$ \\
\hline LN SIZE & $\begin{array}{c}0,106^{* * *} \\
(5,42)\end{array}$ & $\begin{array}{c}-0,009 \\
(-0,68)\end{array}$ & $\begin{array}{c}0,068^{* * *} \\
(4,28)\end{array}$ \\
\hline LN AGE & $\begin{array}{c}0,011 \\
(0,39)\end{array}$ & $\begin{array}{c}-0,062^{* * *} \\
(-3,24)\end{array}$ & $\begin{array}{l}0,011 \\
(0,43)\end{array}$ \\
\hline DEBT & $\begin{array}{l}-0,108 \\
(-1,21)\end{array}$ & $\begin{array}{c}-0,028 \\
(-1,03)\end{array}$ & $\begin{array}{c}-0,032 \\
(-0,46)\end{array}$ \\
\hline INTANGIBLE & $\begin{array}{l}-0,291 * * \\
(-2,13)\end{array}$ & $\begin{array}{c}-0,051 \\
(-1,28)\end{array}$ & $\begin{array}{c}-0,179 \\
(-1,49)\end{array}$ \\
\hline ECONOMIC RETURN- & $-0,933 * * *$ & $-0,082 * *$ & $-0,726^{* * * *}$ \\
\hline ECONOMIC RETURN YEAR & $(-5,51)$ & $(-2,19)$ & $(-4,95)$ \\
\hline CAPITAL INTENSITY & $\begin{array}{c}-0,048^{* * *} \\
(-4,45)\end{array}$ & $\begin{array}{l}0,001 \\
(0,15)\end{array}$ & $\begin{array}{l}-0,047 * * * \\
(-5,19)\end{array}$ \\
\hline STRUCTURAL CHANGE & $0,412^{* * *}$ & $0,699^{* * *}$ & $0,293^{* * *}$ \\
\hline $\begin{array}{c}\text { DUMMY } \\
\text { CONSTANT }\end{array}$ & $\begin{array}{c}(4,69) \\
-0,505^{*} \\
(-1,90) \\
\end{array}$ & $\begin{array}{c}(18,06) \\
0,341^{*} \\
(1,78)\end{array}$ & $\begin{array}{c}(3,91) \\
-0,216 \\
(-0,99) \\
\end{array}$ \\
\hline $\mathbf{R}^{2}$ & 0,3339 & 0,9352 & 0,2940 \\
\hline $\mathbf{N}$ & 564 & 564 & 564 \\
\hline Breusch-Pagan & $1038,95^{* * *}$ & $1107,19^{* * *}$ & $1013,45^{* * *}$ \\
\hline Wald-Wooldridge & 0,51 & $2,59 * * *$ & 0,72 \\
\hline $\mathrm{Chi}^{2}$ Wald & $181,94 * * *$ & $65156,08^{* * *}$ & $142,32 * * *$ \\
\hline
\end{tabular}

NOTE PCSE (RE): Panel Corrected Standard Errors (random effects); PCSE (FE): Panel Corrected Standard Errors (fixed effects)

All regression results are corrected for heteroskedasticity. Does not exist multicollinearity (VIF $<10$ ).

$*, * *, * * *$ Significant at the $10 \%, 5 \%$ and $1 \%$ levels, respectively 
Table 3: Impact of family ownership on degree and type of diversification: existence of a non-linear relationship

\begin{tabular}{|c|c|c|c|}
\hline & $\begin{array}{c}\text { TOTAL } \\
\text { DIVERSIFICATION } \\
\text { PCSE (RE) } \\
\text { (Model 1) }\end{array}$ & $\begin{array}{c}\text { RELATED } \\
\text { DIVERSIFICATION } \\
\text { PCSE (FE) } \\
\text { (Model 2) }\end{array}$ & $\begin{array}{l}\text { UNRELATED } \\
\text { DIVERSIFICATION } \\
\text { PCSE (RE) } \\
\text { (Model 3) }\end{array}$ \\
\hline \%5 MAIN SHAREHOLDERS * & $-0,620^{* *}$ & $-0,121$ & $-0,503^{* *}$ \\
\hline FAMILY & $(-2,29)$ & $(-0,60)$ & $(-2,25)$ \\
\hline (\% 5 MAIN SHAREHOLDERS * & $0,690^{* *}$ & 0,087 & $0,495^{*}$ \\
\hline FAMILY) ${ }^{2}$ & $(2,20)$ & $(0,56)$ & $(1,92)$ \\
\hline LN SIZE & $\begin{array}{c}0,107^{* * *} \\
(5,40)\end{array}$ & $\begin{array}{l}-0,009 \\
(-0,69)\end{array}$ & $\begin{array}{c}0,070^{* * * *} \\
(4,34)\end{array}$ \\
\hline LN AGE & & $\begin{array}{l}-0,062 * * * \\
(-3,22)\end{array}$ & $\begin{array}{l}0,009 \\
(0,34)\end{array}$ \\
\hline DEBT & $\begin{array}{c}-0,108 \\
(-1,23)\end{array}$ & $\begin{array}{l}-0,030 \\
(-1,08)\end{array}$ & $\begin{array}{l}-0,035 \\
(-0,49)\end{array}$ \\
\hline INTANGIBLE & $\begin{array}{l}-0,269 * * \\
(-1,97)\end{array}$ & $\begin{array}{l}-1,00) \\
-(-1,18)\end{array}$ & $-0,176$ \\
\hline ECONOMIC RETURN- & $-0,887 * * *$ & $\begin{array}{l}(-1,08) * * \\
-0,083^{* * *}\end{array}$ & $-0,709^{* * *}$ \\
\hline ECONOMIC RETURN YEAR & $(-5,41)$ & $(-2,23)$ & $(-4,93)$ \\
\hline CAPITAL INTENSITY & $\begin{array}{l}-0,047 * * * \\
(-4,36)\end{array}$ & $\begin{array}{l}0,000 \\
(0,11)\end{array}$ & $\begin{array}{l}-0,047 * * * \\
(-5,11)\end{array}$ \\
\hline STRUCTURAL CHANGE & $0,399^{* * *}$ & $1,039^{* * *}$ & $0,285^{* * *}$ \\
\hline $\begin{array}{c}\text { DUMMY } \\
\text { CONSTANT }\end{array}$ & $\begin{array}{c}(4,45) \\
-0,497 *\end{array}$ & $\begin{array}{l}(17,58) \\
0,363^{*}\end{array}$ & $\begin{array}{r}(3,74) \\
-0,232\end{array}$ \\
\hline CONSTANT & $(-1,90)$ & $(1,88)$ & $(-1,07)$ \\
\hline $\mathbf{R}^{2}$ & 0,3326 & 0,9355 & 0,2927 \\
\hline N & 564 & 564 & 564 \\
\hline Breusch-Pagan & $1025,40^{* * *}$ & $1084,28^{* * *}$ & $1012,58^{* * *}$ \\
\hline Wald-Wooldridge & 0,38 & $1,65^{*}$ & 0,39 \\
\hline $\mathrm{Chi}^{2}$ Wald & $168,18^{* * *}$ & 64587,82 & $135,61 * * *$ \\
\hline
\end{tabular}

NOTE. PCSE (RE): Panel Corrected Standard Errors (random effects); PCSE (FE): Panel Corrected Standard Errors (fixed effects)

All regression results are corrected for heteroskedasticity. Does not exist multicollinearity (VIF $<10)$.

All regression results are corrected for heteroskedasticity. Does
$*, * *, * * *$ Significant at the $10 \%, 5 \%$ and $1 \%$ levels, respectively 